\title{
Teacher Degree Students Attitudes Towards STEM Activities in two Spanish Universities
}

\begin{abstract}
Aitzol Lasa ${ }^{1}$, Haritz Iribas ${ }^{2}$, Olga Belletich ${ }^{3}$, Miguel R. Wilhelmi ${ }^{4}$
${ }^{1}$ Mathematics Department, Faculty of Education, Public University of Navarre, 31006 Arrosadia Campus, Pamplona, Spain (aitzol.lasa@unavarra.es) ORCID 0000-0001-7267-6614; ${ }^{2}$ Science Department, Faculty of Education, Mondragon University, 20540 Eskoriatza, Dorleta, Spain (hiribas@mondragon.edu) ORCID 0000-0003-4260-2379; 3Pedagogy Department, Faculty of Education, Public University of Navarre, 31006 Arrosadia Campus, Pamplona, Spain (olga.belletich@unavarra.es) ORCID 0000-0003-2676-6453; ${ }^{4}$ Mathematics Department, Faculty of Education, Public University of Navarre, 31006 Arrosadia Campus, Pamplona, Spain (miguelr.wilhelmi@unavarra.es) ORCID 0000-0002-6714-7184
\end{abstract}

\begin{abstract}
The attempt to train undergraduate primary school teachers in STEM skills faces an evident handicap, since students enrolling Teacher Degrees usually have humanistic secondary school backgrounds. Attitudes towards STEM on a sample of 336 undergraduate teachers from two Spanish universities were analyzed. Students answered a questionnaire, and responses were analyzed qualitatively (open text questions) and quantitatively (Descriptive Statistics and Statistical Implicative Analysis). Results describe a young collective, with a clear majority of women, mostly interested in languages and history, with high vocation (rather spontaneous than hereditary) to work with children. There is evidence that school advice services fulfill a role to discourage certain students from STEM. These conclusions give valuable information that could be used to replace institutional practices and improve the perception future teachers have towards the teaching of STEM in Primary Education.
\end{abstract}

Author Keywords. Initial Teacher Training, Primary Education, STEM Education, School Advice.

Type: Research Article

$\partial_{\text {Open Access }} \square$ Peer Reviewed $@$ (1) CC BY

\section{Introduction}

Relationships between socio-familial context and academic performance are already known (Lambert-Le Mener 2012). In addition, the influence of context on taste and interest in different subjects is well known (Cosnefroy 2007). Even more, teachers' spontaneous epistemology (Brousseau 2002) underlies many of the reflections, analyses, and behaviors of Teachers in Initial Training (TIT). Finally, it has been learned that TIT stereotype Education (Belletich and Villarreal Zufiaurre 2014). Therefore, "international literature on the educational influence of males on children, and more generally on 'gender balance' in the Early Childhood Education and Care (ECEC) workforce, has increased gradually over the past 15 years" (Huber and Traxl 2018). However, not much information is available regarding TIT's interest in the STEM field, that allows us to foresee actions for the improvement of education. In the framework of an agreement with the Government of Navarre (Spain), proposals for the integrated work of Science, Technology, Engineering and Mathematics (STEM) in secondary schools, have been analyzed from 2019 to 2021. In addition, a special effort has been made to introduce STEM proposals in the initial teacher training of future teachers at university, as well as to analyze the attitudes of these future teachers regarding those proposals. 
Among other things, one of the great challenges in the initial teacher training is that future teachers can learn to give meaning to children's learning in schools (Carruthers and Worthington 2006), as well as being active and conscious participants in their own training (Galvão, Ponte, and Jonis 2018). In short, be empowered for teaching that leads to the development of different areas and capabilities (Tardif 2002).

The STEM context offers several advantages (Lasa et al. 2021a). A project that integrates scientific, technological, engineering and mathematics fulfills the curriculum principle (NCTM 2000 ) and plays the role of an antagonistic milieu within a didactical situation (Brousseau 2002). Also, the use of software in these proposals (for example, dynamic geometry), favors and aids students' mathematical activity (Lasa 2015). Suitable activities reinforce challenge, inventiveness, autonomy and technological literacy (Cruz Guerra and Lupiáñez Gómez 2019), all elements related to a didactical situation.

In relation to the mathematical content used in STEM activities, it can be stated that they are mostly basic and utilitarian, related to the measurement of magnitudes, statistical interpretation of numbers and the use of fundamental geometric language (Lasa, Abaurrea, and Iribas 2020). Therefore, students do not require previous complex knowledge of mathematics to address STEM activities, and the activity itself is a potential adidactical situation, where students put into practice their personal problem-solving skills. Afterwards, the teacher could make use of this resort to formalize the arithmetical, algebraic, and functional contents arising from the activity into their institutional meaning (Godino et al. 2015). Furthermore, case studies show (Lasa et al. 2022) that the latter can be done, improving the integration of dynamic software and the use of the scientific method into technological laboratory tasks.

Since it is already known about the structure and specificities of STEM projects in secondary schools, this paper focuses on the previous step. Thus, the attitudes and beliefs that primary school teachers show about science and mathematics teaching are analyzed.

On the one hand, a principal group of high-rating female students coming from humanistic baccalaureates into primary school teacher degrees can be easily identified (Lasa et al. 2021b). External factors, such as the change of social perception towards Teacher Degrees or the increase of the number of competitive examinations, explain the progressive increase in the admission rate. Other factors internally contribute to this phenomenon, such as the implementation of International Programs and Double Degrees, which attract high-grade students by call-effect.

In fact, at present, both the International Programs, in which the vehicular language is a foreign language (generally English), and the Double Degrees, in which two university degrees are studied simultaneously, are socially highly valued and, therefore, are in great demand in Spanish universities. As a result, the cut-off mark for these degrees is usually very high, having a "dragging effect" on the admission cut-off mark for the rest of the programs (Table 1).

On the other hand, there is a smaller group of students, composed of equally men and women, coming from scientific baccalaureates who get into Teacher Degrees. This secondary group provides a scientific and technological profile to a fundamentally social discipline, which must be understood as a fortress to introduce STEM proposals into primary school teacher degrees.

Finally, although students coming from humanistic baccalaureates form a homogeneous body within primary school teacher degrees, there is also a small segment of this population which enters the degree with the lowest access rate. In other words, the different profiles are 
heterogeneously distributed in the access list, except for the last positions, which are mostly occupied by students from humanities baccalaureate programs.

\begin{tabular}{|c|c|c|c|c|c|c|c|}
\hline Academic year & $15 / 16$ & $16 / 17$ & $17 / 18$ & $18 / 19$ & $19 / 20$ & $20 / 21$ & $21 / 22$ \\
\hline BD Early Childhood ED & 6,946 & 7,190 & 6,910 & 7,310 & 7,839 & 8,770 & 9,040 \\
\hline BD Primary ED & 7,051 & 7,150 & 7,000 & 7,360 & 7,850 & 8,524 & 9,322 \\
\hline INTER BD Early Childhood ED & --- & --- & 6,973 & 7,620 & 8,035 & 9,262 & 9,353 \\
\hline INTER BD Primary ED & --- & --- & 7,444 & 7,631 & 8,320 & 8,559 & 9,732 \\
\hline 2 BD Early Childhood ED \& Primary ED & -- & --- & --- & --- & 10,482 & 11,350 & 11,641 \\
\hline 2 INTER BD Early Childhood ED \& Primary ED & --- & --- & --- & --- & --- & 11,394 & 11,891 \\
\hline \multicolumn{8}{|l|}{ Legend } \\
\hline $\begin{array}{l}\text { Maximum mark in compulsory phase: 10; Max. } \\
-\quad \text { BD Early Childhood ED: Bachelor's Degre } \\
-\quad \text { BD Primary ED: BD in Primary Education } \\
-\quad \text { INTER BD Early Childhood ED: Internatio } \\
-\quad \text { INTER BD Primary ED: International BD i } \\
-\quad 2 \text { BD Early Childhood \& Primary ED: Dou } \\
-\quad 2 \text { INTER BD Early Childhood \& Primary EL } \\
\quad \text { \& Primary Education }\end{array}$ & $\begin{array}{l}\text { nal BD ir } \\
\text { Primar } \\
\text { ole BD ir } \\
\text { D: Intern }\end{array}$ & $\begin{array}{l}\text { narly C } \\
\text { y Educa } \\
\text { n Early C } \\
\text { lational }\end{array}$ & $\begin{array}{l}\text { hildhoo } \\
\text { tion } \\
\text { hildhoo } \\
\text { Double }\end{array}$ & $\begin{array}{l}\text { e: } 4 ; \mathrm{Ma} \\
\text { d Educa }\end{array}$ & $\begin{array}{l}\text { x. overall } \\
\text { tion }\end{array}$ & mark: 1 & \\
\hline
\end{tabular}

Table 1: Cut-off marks for admission in Teacher Degrees

Likewise, we are aware that, to understand the profile and attitudes for STEM subjects, with which future teachers face these types of studies, we must recognize that a large part of those features is proper of the current society and culture. Some authors (Gimeno Sacristán 2005; Hudson and Zgaga 2008) argue that training models cannot be alien to that social profile, nor to the changes introduced in the way of perceiving the role of education in the globalized world and in an information society.

\section{Materials and Methods}

The population of this study is composed of 520 Teachers in Initial Training (TIT) who enrolled their first academic year in Teacher Degrees in two Spanish Universities in 2019/2020 (Table 2). TIT are previously informed of the content, interest and use of the questionnaire. The questionnaire is voluntary and anonymous.

\begin{tabular}{ccc}
\hline & Population & Sample \\
\hline University 1 & 308 & 171 \\
University 2 & 212 & 165 \\
\hline Table 2: Size of population and sample
\end{tabular}

TIT access the questionnaire through the official virtual platform in the Universities. These platforms include numerous tools to promote online cooperative work and communication between users; in particular, they allow the completion of anonymous questionnaires. Access to these virtual platforms in universities requires validation with a unique personal identifier and a personal password, which meets the standard security criteria and is not shared among several users or communicated to third parties. This encrypted login is therefore a sign of individual consent.

In short, the criteria of prior information, anonymity and individual consent necessary for the exploitation of content are met.

The sample includes the answers of 336 TIT (64.6\% of the population) to a questionnaire on their beliefs in relation to the teacher studies that have just begun, and on their perception of scientific subjects in teacher studies. 
Students enrolled at University 1 perform studies in either Child Education Teachers Degree (CE), Primary Education Teachers Degree (PE), or Double Degree in both Child and Primary Education (DG), in Basque or Spanish language (Table 3). Each degree also includes a foreign language immersion itinerary called the International Program (IP). Students enrolled at University 2 are undergoing Teacher Degrees in Child or Primary Education in Basque language.

\begin{tabular}{ccccc}
\hline & CE & PE & DG & Total \\
\hline University 1 & 52 & 101 & 18 & 171 \\
University 2 & 42 & 123 & -- & 165 \\
\hline Total & 94 & 224 & 18 & 336 \\
\hline \multicolumn{5}{r}{ Table 3: Size of population and sample }
\end{tabular}

The sample is mostly female (72.9\%), with a hegemonic presence of women in CE $(94.7 \%)$, without any other significant variation in the proportion between men and women, in relation to language or other variables. The sample is also young, only $8 \%$ of the sample are older than 20 years, and just $1.8 \%$ are older than 22 years. In other words, most TIT are in their natural age at the beginning of university studies, around $18 / 19$ years old (Figure 1 ).

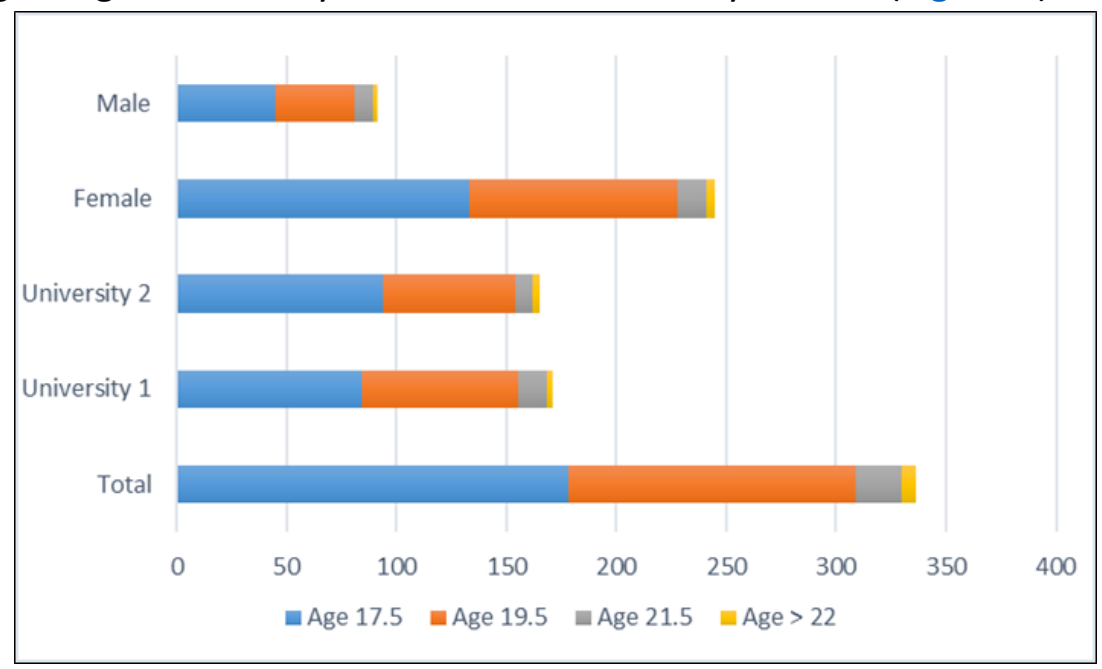

Figure 1: Age distribution by university and gender

TIT have previously completed several pathways in Compulsory Secondary Education (CSE) and Post-Compulsory Education (Baccalaureate or Vocational Training). Most of them have completed humanistic (51.7\%) or scientific-technological (41.6\%) CSE pathways (Table 4), with a small number of TIT having completed compulsory studies at other artistic or vocational pathways (6.5\%).

\begin{tabular}{lcccccc}
\hline & Arts & Humanistic & Science & VT $^{{ }^{1}}$ & Other & Total \\
\hline University 1 & 7 & 86 & 75 & 3 & 0 & 171 \\
University 2 & 2 & 88 & 65 & 6 & 4 & 165 \\
\hline \multicolumn{1}{c}{ Total } & 9 & 174 & 140 & 9 & 4 & 336 \\
\hline${ }^{1}$ Vocational training & & &
\end{tabular}

Table 4: Students distribution by CSE pathways

In post-compulsory education, the percentage of TIT who have attended high school in humanistic branches increases (60.7\%), while only half of the TIT initially planned to undertake scientific and technological studies continue with this option (22.6\%). A total of $7.7 \%$ of students are enrolled in artistic formation, while $8.3 \%$ continue their studies in Vocational Training pathways (Table 5). 


\begin{tabular}{ccccccc}
\hline & Arts & Humanistic & Science & VT $^{{ }^{1}}$ & Other & Total \\
\hline University 1 & 22 & 94 & 34 & 20 & 0 & 171 \\
University 2 & 4 & 110 & 42 & 6 & 2 & 165 \\
\hline Total & 26 & 204 & 76 & 26 & 2 & 336 \\
\hline
\end{tabular}

${ }^{1}$ Vocational training

Table 5: Students distribution by Baccalaureate and VT pathways

The description of the sample gives us a preliminary idea of the vital itinerary of TIT before they access University degrees and is used in the dichotomous coding of the external variables of the sample that describe personal data and the formation of TIT. Thus, variables 1 to 9 describe external factors such as university, language, gender, age, which degree they enrolled in, or the previous CSE and Baccalaureate pathway they followed (Appendix A).

The answers to the questionnaire regarding TIT taste for the disciplines, their socio-familiar environment and personal positioning in relation to science and mathematics are codified by the dichotomous internal variables 10 to 62 (Appendix B). All variables have been analyzed both by descriptive statistics and by statistical implicative analysis (Gras et al. 2008), and the full questionnaire is available in Appendix C.

\section{Results}

When asked about their tastes or interests related to their pre-university education (Figure 2), TIT show a taste or interest in three subjects or disciplines, which stand out for their greater frequency over others; these are, respectively: History \& Arts, Language \& literature, and Mathematics. In a second level, the subjects of Biology, Artistic Drawing and Technology follow at some distance. All the others are cited less frequently. Each TIT highlights up to three options in their answers, and from the point of view of science teaching, it should be noted that 204 TIT (60.7\%) appoint at least one science subject in these options.

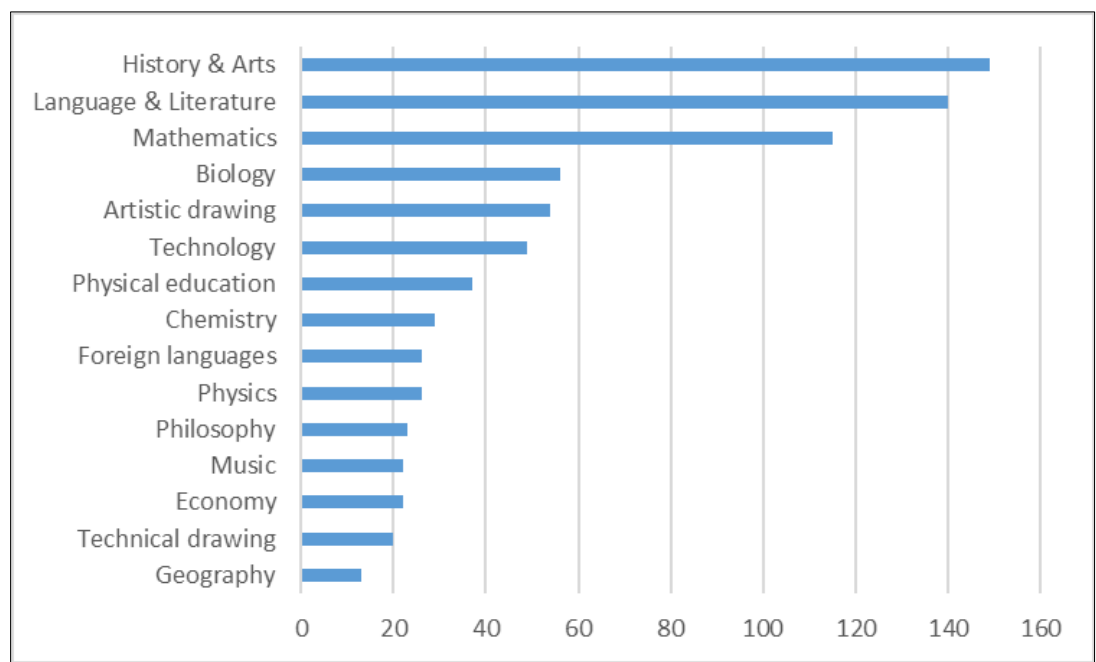

Figure 2: Absolute frequency of pre-university taste and interests stated

When asked for the reasons why they chose Teacher Degrees, TIT mostly answered that they always liked to interact with children (78.2\%) and, that they saw themselves from time ago working as teachers (61.9\%). On a second level, $28.3 \%$ of TIT justify their admission to Teacher Degrees because they consider them to be exciting. Only 3.9\% admit entering Teacher Degrees because they consider these studies easy to perform, and the number of TIT that justify their admission to Teacher Degrees because they consider that they have more options to obtain a University Degree is even lower (3.3\%). 
Considering the hypothesis of abolishing the obligation to pursue a particular subject in Teacher Degrees, $62.5 \%$ of TIT consider that experimental sciences, i.e., Physics \& Chemistry, should not be mandatory. Secondly, natural sciences are cited, i.e., Biology \& Geology (17.8\%). They are followed by Foreign Languages (12.2\%) and Language \& Literature (10.7\%). The disciplines least likely to be optional in the curricula would be Mathematics (9.8\%) and History \& Arts (8.6\%).

TIT are mostly against the suppression of the disciplines of Language \& Literature and Foreign Languages from the curricula (Figure 3), followed by Social Sciences and Mathematics. Experimental Sciences are once again in the last place.

Related to the family environment of the sample, $60.4 \%$ of TIT state that at least one parent has higher university studies, and $36.3 \%$ say that at least one parent has higher technical studies. Among them, $29.8 \%$ belong to higher or technical studies in scientific and technological fields. On the other hand, $11.9 \%$ did not have any higher or technical education. Most TIT (66.4\%) expect to be able to share with their family environment a new point of view on teacher studies, $42.9 \%$ expect to be able to consult their day-to-day problems in their family environment, while $27.7 \%$ expect their family environment to contribute to a theoretical framework of study.

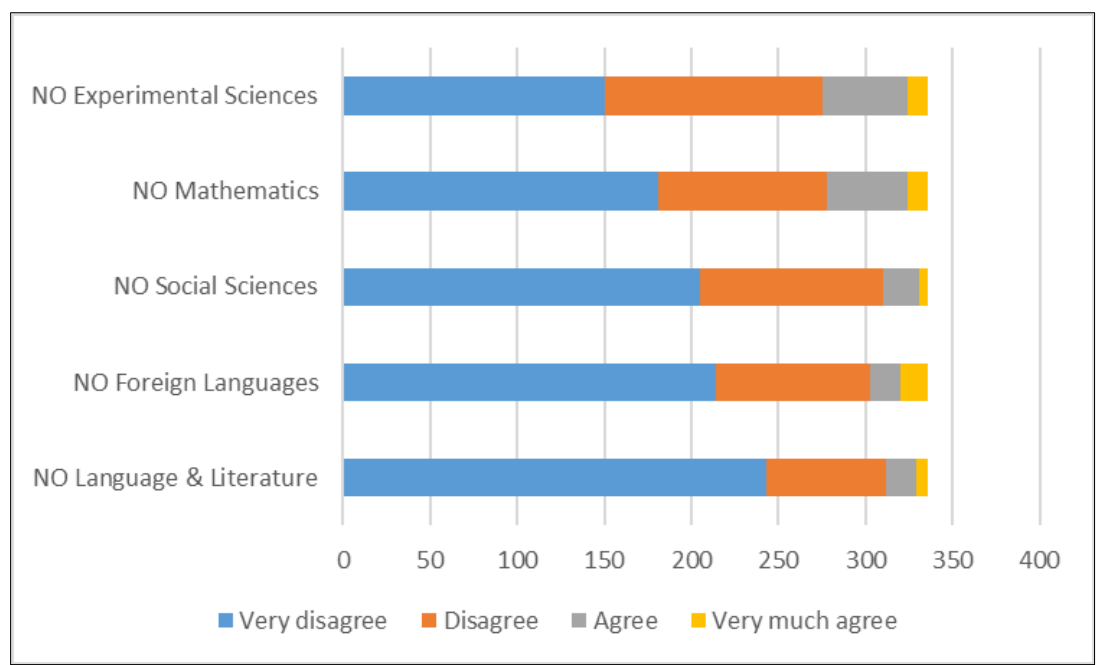

Figure 3: Absolute frequency of stated opinion against the suppression of different disciplines at university

$65.5 \%$ state that their family environment has not transmitted them any notion of the importance of artistic or scientific disciplines. $29.8 \%$ say that in their family environment they have been taught to love arts, while $20 \%$ state that they have been taught to love sciences. In relation to the latter, $38.1 \%$ of the TIT add that their family environment has transmitted them the convenience of studying a scientific career. $62.5 \%$ know a close person engaged in education, but only $13.1 \%$ have a parent who is teacher at child or primary education, and $8.9 \%$ have a parent who is teacher at CSE or baccalaureate levels.

Finally, regarding mathematics, $34.2 \%$ of TIT acknowledge that they like mathematics and $42.0 \%$ show their willingness to continue studying them. On the other hand, $43.8 \%$ are resigned to continue studying mathematics because they acknowledge the importance they have, while $14.6 \%$ confessed that they do not want to see them in their lives.

The similarity tree (Figure 4) and the implicative graph (Figure 5) of the implicative statistical analysis classify the study variables (which it can be found in the appendices) into up to 12 groups, depending on their degree of linkage. The smaller groups do not provide relevant 
information, because there are few subjects in them, so it is not easy to give them a meaning. Therefore, three main groups are considered:

Variables [[[2, 22], 28], 51], 50]. This first cluster links students' transmission and foreign languages, i.e., students who enroll university in Spanish language are close to the learning of other foreign languages (mostly English). They rely on the profession-al value of Teacher Degrees, and they have a favorable family environment with which to consult theoretical aspects related to their subjects of study.

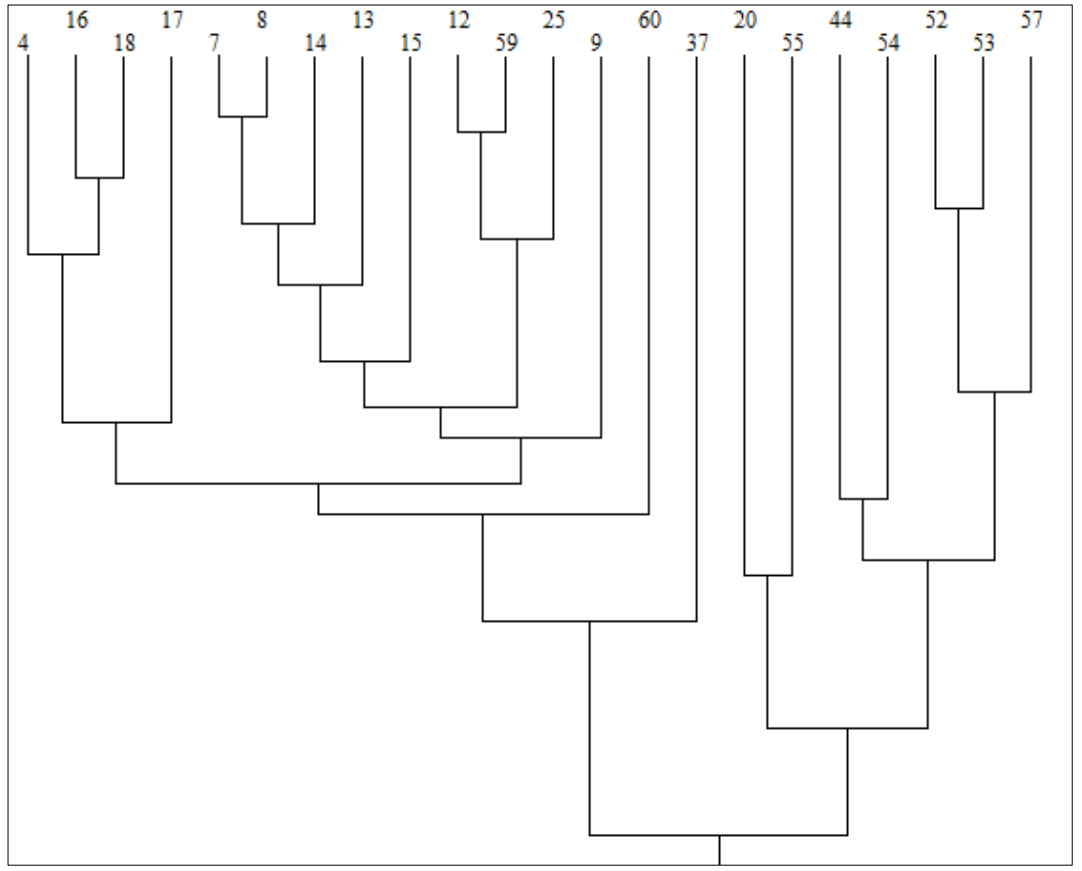

(a)

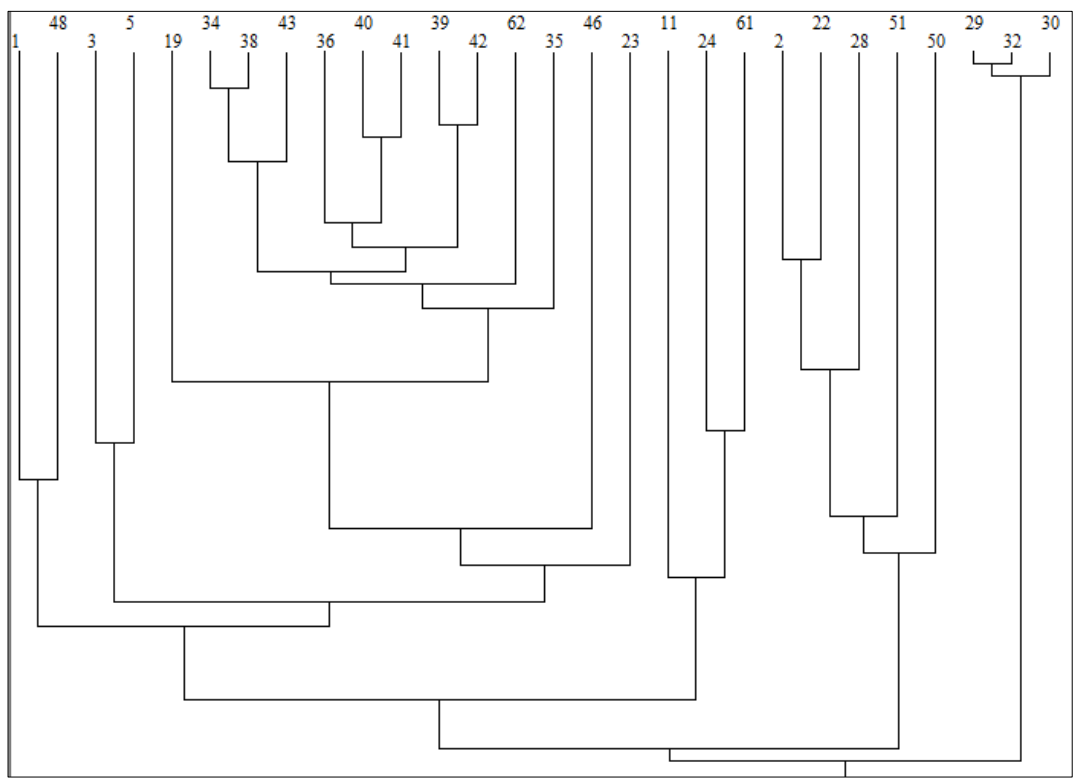

(b)

Figure 4: Caption of the similarity-tree from the implicative statistical analysis. The similarity tree classifies study variables into 12 groups, depending on their degree of linkage. Three main groups are considered, since the smaller groups do not provide relevant information, due to their small size.

(a) First cluster (b) Second and third clusters. 


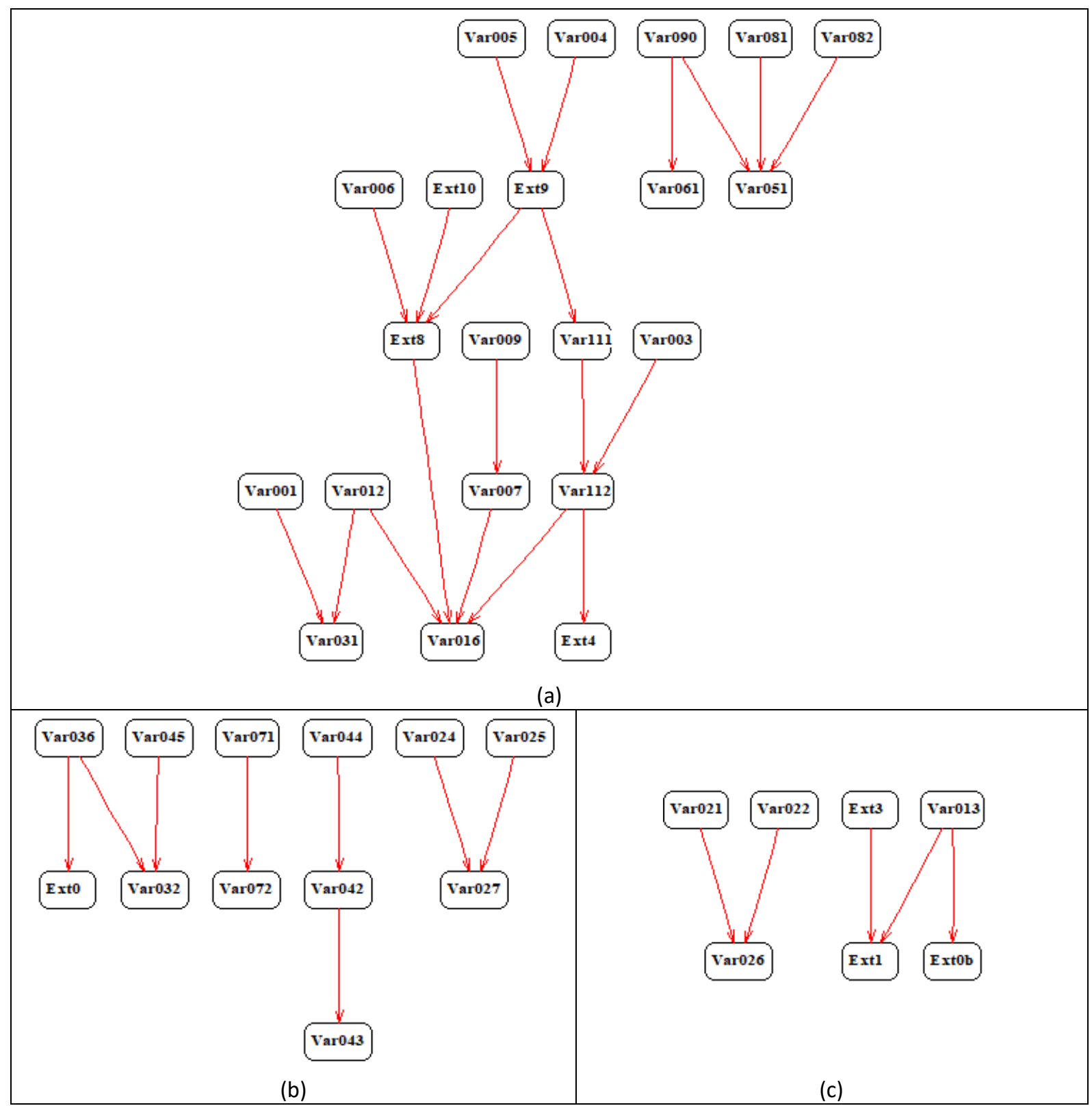

Figure 5: Caption of the implicative graph from the implicative statistical analysis. Only relations at $99 \%$ among variables are shown, which are consistent with the similarity tree

Variables [[[[[7, 8], 14], 13], 15], [[12, 59], 25], 9]. This second cluster links students who studied science pathways in CSE or Baccalaureate, with a taste for both experimental and natural sciences (physics, chemistry, and biology) and mathematics. This second cluster has two clear subgroups.

Variables [[4, [16, 18], 17]. This first branch identifies older students who enroll in Teacher Degrees coming from previous Vocational Training studies. They have a taste for technological disciplines, and they are keen on technical and artistic drawings.

Variables [Previous, 60]. The union of the previous variables to variable 60 states that students who change from a scientific CSE to a humanistic Baccalaureate maintain a taste for mathematics and their intention to continue studying them.

Variables [[19, [[[34, 38], 43], [[36, [40, 41]]], [39, 42]]], 62], 35], 46], 23]. The third and final cluster links students who consider that Foreign Languages, Language \& Literature, Mathematics and Biology should not be mandatory in Teacher Degrees. They also find Foreign 
Language, Mathematics, Experimental Sciences, Social Sciences, and Language \& Literature susceptible of elimination from the curriculum. These same students explicitly reject Mathematics, and they state their intention not to see them again in their lives. The variables are related to students whose parents or legal guardians do not have university or higher technical studies. The only subjects which appear to be linked to the personal tastes of this group are Music and Philosophy.

The similarity tree shows that CE is strongly linked to the female gender (variables 3 and 5). Students with greater attachment to History or Geography recognize the importance of studying mathematics and explain their intention to follow them, even if they admit that they are not particularly attracted to the discipline (variables 11, 24 and 61). The few students who claim to enroll in Teacher Degrees because they consider them to be easy and more likely to graduate appear isolated from any other variable (variables 29, 30 and 32). Parents or legal guardians with a higher level of education more frequently transmit their taste in arts and sciences to their children. Art lovers double in number science lovers, but science lovers are included in the set of art lovers, and not the other way around.

\section{Discussion}

The sample shows that TIT are mostly high-rate young women enrolling University in their natural age; only a quarter of the sample are men, and only $8 \%$ are older than 21 years. The presence of women is hegemonic in CE. In their previous CSE studies, TIT have undergone equally humanistic or scientific pathways (Table 6). However, when promoting from CSE to Baccalaureate or VT, half of the TIT abandon the science pathway to move, above all, onto a humanistic pathway.

\begin{tabular}{ccccccc}
\hline & Arts & Humanistic & Science & VT $^{1}$ & Other & Total \\
\hline CSE & 9 & 174 & 140 & 9 & 4 & 336 \\
Baccalaureate or VT & 26 & 204 & 76 & 26 & 2 & 336 \\
\hline Difference & +17 & +30 & -64 & +17 & -2 & 0 \\
\hline${ }^{1}$ Vocational training & & & &
\end{tabular}

Table 6: Pathways divergence from CSE to Baccalaureate

There is a usual flow of students from any CSE pathway to any other Baccalaureate pathway. The origin of this flow could be found in the personal initiative of students who, at the end of the CSE stage, discover a certain vocation and decide to modify their initial study-plan, enrolling in a different Baccalaureate than the foresee. However, the flow of students moving from scientific CSE pathways to humanistic Baccalaureates is much bigger than any other. For example, $1.7 \%$ of students move out from a humanistic CSE pathway to different ones; while 48.6\% move out from science CSE pathways (Table 7). The artistic baccalaureate pathways, although a minority, do not suffer any losses and only receive talent in this process.

\begin{tabular}{ccccc}
\hline From/To & Arts & Humanistic & Science & Other \\
\hline Arts & 9 & 0 & 0 & 0 \\
Humanistic & 7 & 145 & 4 & 16 \\
Science & 8 & 55 & 72 & 5 \\
Other & 2 & 0 & 0 & 9 \\
\hline
\end{tabular}

Table 7: Flow from CSE to Baccalaureate

The humanistic profile of the sample is evident, and the taste for History \& Arts and Language \& Literature stand out in all other disciplines. However, it is relevant that Mathematics appears in the third-place within this framework, because it is indicative of the importance that TIT give to mathematics education. 
The position of mathematics is stable within all segments of the sample (vehicular language, age, degree, etc.), except for the segment of International Program students, in which Foreign Languages take the position of Mathematics (Table 8). In this segment, Language \& Literature rank first, while natural and experimental sciences (biology, physics, and chemistry) are relegated to the last positions. While more than half of TIT in the sample (60.7\%) fancied at least one science subject, in the International Program this percentage is $43.7 \%$.

\begin{tabular}{cccc}
\hline Sample & $\%$ & International Program & $\%$ \\
\hline History \& Arts & 44.4 & Language \& Literature & 46.9 \\
Language \& Literature & 41.7 & History \& Arts & 40.6 \\
Mathematics & 34.2 & Foreign Language & 34.4 \\
\hline Biology & 16.6 & Mathematics & 31.3 \\
Chemistry & 8.6 & Physics & 9.4 \\
Physics & 7.7 & Chemistry & 3.1 \\
Foreign Language & 7.7 & Biology & 3.1 \\
\hline
\end{tabular}

Table 8: Influence of IP in STEM perception

One might think that the privileged position of Foreign Languages would compensate for the lack of interest or attachment to STEM disciplines of IP- TIT, who would benefit from a superior domain in foreign languages, to the detriment of a taste for science.

To check this hypothesis, we compare the Foreign Language (English) qualifications of the University 1 population (308 TIT, plus 80 additional TIT that attend the same subject in a second enrolment) in 2019/2020. Table 9 shows that the average performance of the TIT segment that goes through the IP is not significantly better: the mean rating is 6.36 over 10 in both segments. On the other hand, the average score obtained by the DG-TIT is 8.37, with a greater dispersion.

\begin{tabular}{cccc}
\hline & $\mathbf{N}$ & $\mathbf{X}$ & $\mathbf{s}$ \\
\hline Regular group & 324 & 6.92 & 1.29 \\
International Program & 36 & 6.36 & 1.10 \\
Double Degree & 28 & 8.37 & 1.77 \\
\hline Population & 338 & 6.36 & 1.38 \\
\hline
\end{tabular}

Legend: $\mathrm{N}$ : absolutely frequency; $\mathrm{x}$ : mean; s: standard dispersion.

Table 9: English language qualifications, University 1

The vocational profile of the TIT sample is evident. 93.2\% justified their enrolment to Teacher Degrees alleging either their desire to interact with children or their long-term self-perception to work with children. In this sense, in Spanish context, the results strengthen the location of Teacher Degrees within the spectrum of other socially feminized labor activities linked to community care. It is also significant the low percentage $(5.4 \%)$ of answers that describe Teacher Degrees as easy or affordable. This result helps to dismantle the myth that students who opt for Teacher Degrees do so because they are easier than other university degrees. Finally, it is also confirmed the existence of a group of TIT that values Teacher Degrees and gives them a category of exciting (28.3\%).

It is evident that experimental sciences are at the forefront of the perception that TIT have about non-relevant disciplines in Teacher Degrees. If a discipline had to be eliminated, experimental and natural sciences should not be part of the curriculum, whereas Language \& Literature, Foreign Languages and Social Sciences should remain. Even Mathematics are out of the question in teachers initial training, despite de humanistic profile of the sample. 
In general, TIT hope to share their day-to-day academic problems and their view on Teacher Degrees with a family environment characterized by higher education. This family environment is not directly linked to the educational system nor has a direct impact on the transmission of favorable beliefs towards arts and sciences. Families just give positive advice about the advantages of studying scientific careers at university, because they re-produce the pragmatic and opportunistic perception that they facilitate access to a job. In any case, $71.9 \%$ of TIT that have received positive stimuli toward science have also received it for all disciplines (Figure 6), both scientific and humanistic.

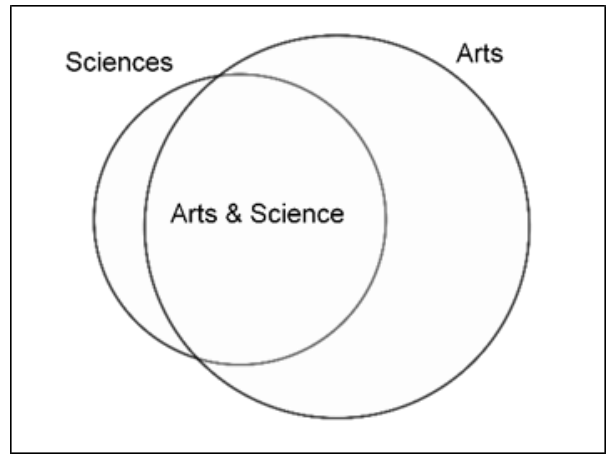

Figure 6: Arts \& Science intersection

There are three large typologies among TIT; these would be:

TIT with humanistic profile. Students with a taste for language, literature, and foreign languages, who vocationally enroll in Teacher Degrees and who enhance and value the quality of these studies. They consider that teacher careers will provide them with professional development, and they feel the support of their family environment, with which they consider they can share theoretical issues related to the career or to check doubts they have regarding the subjects of study.

TIT with scientific-technological profile. They are divided into two typologies. On the one hand, TIT that perform a complete scientific itinerary from CSE to Baccalaureate show a taste and attachment to all scientific disciplines. On the other hand, the TIT who enroll from vocational training and join university with a higher average age show a greater interest in technological and drawing disciplines, both technical and artistic.

TIT with antipathy or resentment profile. These are TIT that criticize and abhor in a general and indifferent way any human, social or scientific discipline. They openly claim their aversion to mathematics and their hate to keep studying them. The only two disciplines that are free from their hate would be music and philosophy; perhaps because both disciplines can be claimed as alternative, and they do not have a socially recognized practical utility. This profile is linked to a low-rate educational level.

Some links between variables do not provide additional information, but they are sympathetic, such as the recognition by TIT with History \& Geography profile of the importance of studying mathematics and their intention, with a certain amount of resignation, to continue studying them, even though they recognize that they do not feel special attachment to the discipline (variables 11, 24 and 61).

Some other variables provide information for the simple fact that they are not linked to any other: the few students who recognize to enroll Teacher Degrees because they consider them easy or more likely to graduate, appear isolated from any other variable (variables 29, 30 and 32). 


\section{Conclusions}

The teaching profession is a historically feminized labor and social activity linked to community care. International literature on the educational influence of males on children, and more generally on 'gender balance' in the Early Childhood Education and Care (ECEC) workforce, has increased gradually over the past 15 years. This situation persists in the sample, especially in the degree in early childhood education. Teacher Degrees are clearly vocational, and there is a segment or core of TIT that values the importance of initial teacher training as a discipline. This fact would dismantle the myth according to which teachers' is an easy career. In general, TIT have a higher education family environment not directly linked to the educational system, and they receive from that environment the notion that sciences have a certain practical importance, even though they have not been shown specific taste or interest in these scientific disciplines.

Although the age between 12 and 15 years is considered conducive to project and laboratory methodologies (Gras et al. 2008), it is at that same age where the educational system loses some scientific talent. Half of TIT who started their scientific pathways at CSE finished disenchanted with experimental sciences, without detriment to their attachment to mathematics. This fact is reflected in the perception TIT have about experimental sciences and mathematics: they would eliminate the first from teacher training programs, as they consider it the least necessary or relevant in Teacher Degrees; but they would maintain mathematics, because they have greater attachment or taste for the discipline, and because they consider them necessary and important in teacher education and in mandatory educational stages. Therefore, school advice services should be aware of the phenomena to give an institutional answer, in terms of school-advice and promotion of new methodologies and evaluation-tools for science.

The characterization of a specific profile of TIT that shows antipathy and resentment towards the entire set of disciplines disassembles the belief that art students would be in opposition to science students. This fact justifies the need to design a specific access test to discourage heaters before they reach Teacher Degrees (Albarracín et al. 2021) and clarifies that art students do not flee from sciences.

Although TIT have a predominantly humanistic profile, the characterization of a TIT segment with a scientific and technological profile allows to exploit this strength within Teacher Degrees.

The introduction of foreign language immersion programs in mandatory early stages has generated a discourse with strong political content in society, sometimes exceeding the purely pedagogical or didactical (Anghel, Cabrales, and Carro 2013). From the perspective of STEM, there is evidence that these programs provoke in IP-TIT a rearrangement of their beliefs and tastes which reinforces their disinterest in science, without substantially improving their foreign language level with respect to the average student. The time that can be devoted to teaching a particular discipline within the educational system is always finite, and the system must properly order its preferences to obtain an optimal result, not only in the learning outcomes of the different disciplines, but also in the perception that students will develop about them.

There are usually scarce curricular variations at university degrees in the short term, and therefore, the implementation of a new program has a call effect for students with excellent qualifications. The implementation of International Programs in Teacher Degrees initially 
attracted excellent students (Lasa, Abaurrea, and Iribas 2020), but the effect of novelty loses strength over time, and Double Degrees are taking over the call-effect for excellent students.

\section{References}

Albarracín, L., F. Rojas, E. Chandia, F. M. Ubilla, and N. Gorgorió. 2021. "Unidimensionalidad del conocimiento matemático inicial de estudiantes para maestro [One-dimensionality of initial mathematical knowledge of prospective teachers]". In Investigación en Educación Matemática XXIV: 117-24. Valencia: SEIEM.

Anghel, B., A. Cabrales, and J. M. Carro. 2013. Evaluación de un programa de educación bilingüe en España: El impacto más allá del aprendizaje del idioma extranjero [Evaluation of a bilingual education program in Spain: the impact beyond foreign language learning]. Madrid: FEDEA, Universidad Carlos III.

Belletich, O., and M. P. de Villarreal Zufiaurre. 2014. "El imaginario colectivo de la educación en la formación inicial de maestros" [The collective imagination of education in initial teacher training]. In Construyendo la nueva enseñanza superior, 95-106. Madrid: McGraw Hill.

Brousseau, G. 2002. Theory of Didactical Situations in Mathematics: Didactique des Mathématiques, 1970-1990. Springer. https://doi.org/10.1007/0-306-47211-2.

Carruthers, E., and M. Worthington. 2006. Children's Mathematics: Making marks, making meaning. Sage Publications Ltd. https://doi.org/10.4135/9781446213780.

Cosnefroy, L. 2007. "Les sens multiples de l'intérêt pour une discipline ". Revue française de pédagogie 159: 93-102. https://doi.org/10.4000/rfp.1080.

Cruz Guerra, A., and J. L. Lupiáñez Gómez. 2019. "Tareas que fomentan el desarrollo de la competencia STEM [Tasks for mathematical development of STEM competence]". Suma: Revista sobre Enseñanza y Aprendizaje de las Matemáticas no. 90: 31-39.

Galvão, C., J. P. da Ponte, and M. Jonis. 2018. "Os professores e a sua formação inicial". In Práticas de formação inicial de professores: Participantes e dinâmicas, 25-46. Lisboa: Instituto de Educação (Universidade de Lisboa). https://hdl.handle.net/10451/32762.

Gimeno Sacristán, J. 2005. La educación que aún es posible: Ensayos acerca de la cultura para la educación. Madrid: Ediciones Morata, S. L.

Godino, J. D., T. Neto, M. Wilhelmi, L. Aké, S. Etchegaray, and A. Lasa. 2015. "Algebraic reasoning levels in primary and secondary education". In CERME 9 - Ninth Congress of the European Society for Research in Mathematics Education, 426-32. https://hal.archivesouvertes.fr/hal-01286917.

Gras, R., E. Suzuki, F. Guillet, and F. Spagnolo, eds. 2008. Statistical implicative analysis: Theory and applications. Springer. https://doi.org/10.1007/978-3-540-78983-3.

Huber, J., and B. Traxl. 2018. "Pedagogical differences and similarities between male and female educators, and their impact on boys' and girls' behaviour in early childhood education and care institutions in Austria". Research Papers in Education 33, no. 4: 452-71. https://doi.org/10.1080/02671522.2017.1353674.

Hudson, B., and P. Zgaga, eds. 2008. Teacher education policy in Europe: A voice of higher education institutions. Umeå: University of Umeå, Faculty of Teacher Education.

Lambert-Le Mener, M. 2012. "La performance académique des étudiants en première année universitaire: influence des capacités cognitives et de la motivation". PhD diss., Université de Bourgogne. https://tel.archives-ouvertes.fr/tel-00780578. 
Lasa, A. 2015. Jarduera matematikoa eredu dinamikoen laguntzaz [Mathematical practice aid by dynamic models]. Udako Euskal Unibertsitatea.

Lasa, A., J. Abaurrea, and H. Iribas. 2020. "Mathematical content on STEM activities". Journal on Mathematics Education 11, no. 3: 333-46. https://doi.org/10.22342/JME.11.3.11327.333-346.

Lasa, A., M. R. Wilhelmi, O. Belletich, J. Abaurrea, and H. Iribas. 2021a. "STEM projects as didactical situations in mathematics: theoretical frame to construct algebraic institutional meanings". Paper presented at The 14th International Congress on Mathematical Education, Shanghai, China, July 2021.

Lasa, A., O. Belletich, J. Elorza, H. Iribas, and M. R. Wilhelmi. 2021b. "Caracterización del perfil de ingreso a los grados en maestro: Relación entre bachiller científico y género [First year teacher degree students characterization: Relation between science and gender]". In Investigación en Educación Matemática XXIV, 351-58. Valencia: SEIEM.

Lasa, A., A. Lizarraga, A. Sáenz de Cabezón, and I. Irañeta. 2022. "STEM project case study: Construction and calibration of an electronic weighing machine". Paper presented the 12th Congress of the European Society for Research in Mathematics Education, CERME12, Bolzado, Italy, February 2022.

NCTM - National Council of Teachers of Mathematics. 2000. Principles and Standards for School Mathematics. Reston, VA: National Council of Teachers of Mathematics.

Tardif, M. 2002. Saberes docentes e formação profissional. Petrópolis, RJ: Editora Vozes.

\section{Acknowledgments}

This work is part of the Research and Knowledge Transfer Project "Integration of the math curriculum for STEM proposals: design, implementation and evaluation", carried out in Educational Centers Financed with Public Funds of the Government of Navarre (Spain), Resolution 496/2019 of August 8th, National Subsidies Database Code: 448415. 


\section{Appendix A}

\begin{tabular}{|c|c|c|c|}
\hline Ext. Var. & Description & Ext. Var. & Description \\
\hline Var01 & University: University 1; University 2 & Var06 & Primary Education Teacher Degree \\
\hline Var02 & Language: Basque; Spanish & Var07 & CSE pathway: science; humanistic \\
\hline Var03 & Gender: male; female & Var08 & Baccalaureate pathway: science; humanistic \\
\hline Var04 & Age: $17 / 20$ years; more than 21 years & Var09 & Changes pathway from CSE to Baccalaureate \\
\hline Var05 & Child Education Teacher Degree & & \\
\hline
\end{tabular}

\section{Appendix B}

\begin{tabular}{|c|c|c|c|}
\hline Int. Var. & Description & Int. Var. & Description \\
\hline Var10 & $\begin{array}{c}\text { Taste for Language \& Literature in Pre- } \\
\text { University Studies }\end{array}$ & Var39 & Teacher Degrees should NOT include further Social Sciences \\
\hline Var11 & ... History \& Arts ... & Var40 & ... Mathematics \\
\hline Var12 & ... Mathematics ... & Var41 & ... Experimental Sciences \\
\hline Var13 & ... Physics ... & Var42 & ... Language $\&$ Literature \\
\hline Var14 & ... Chemistry ... & Var43 & ... Foreign Languages \\
\hline Var15 & ... Biology ... & Var44 & At least one parent has a College degree \\
\hline Var16 & ... Technology ... & Var45 & At least one parent has a Technical degree \\
\hline Var17 & ... Artistic Drawing ... & Var46 & No parents have higher or technical degrees \\
\hline Var18 & ... Technical Drawing ... & Var47 & A new point of view on working issues \\
\hline Var19 & ... Music \& Audio-Visuals ... & Var48 & New content expected \\
\hline Var20 & ... Physical Education ... & Var49 & The possibility of consultation for everyday problems \\
\hline Var21 & ... Economics ... & Var50 & Sharing my work with others \\
\hline Var22 & ... Foreign Languages ... & Var51 & A theoretical framework to my professional activity \\
\hline Var23 & ... Philosophy ... & Var52 & In my family I have been taught to love science \\
\hline Var24 & ... Geography ... & Var53 & In my family I have been taught to love arts \\
\hline Var25 & $\begin{array}{l}\text { Taste for at least one scientific subject } \\
\text { in Pre-University Studies } \\
\end{array}$ & Var54 & A parent is a CE or PE teacher \\
\hline Var26 & Likes interaction with children & Var55 & A parent is a CSE teacher \\
\hline Var27 & $\begin{array}{l}\mathrm{He} / \text { she sees himself/herself long ago } \\
\text { working as a teacher }\end{array}$ & Var56 & A close person is a teacher \\
\hline Var28 & It is an exciting career & Var57 & A parent has scientific-technological studies \\
\hline Var29 & It is an easy career to study & Var58 & A parent has transmitted taste for science \\
\hline Var30 & More possibilities to graduate & Var59 & I really like math, and I think it is important \\
\hline Var31 & Vocational studies: Var26+Var27 & Var60 & I want to keep studying them to better prepare myself \\
\hline Var32 & Easy studies: Var29+Var30 & Var61 & $\begin{array}{l}\text { If I have to study mathematics, I will, very much to my } \\
\text { regret }\end{array}$ \\
\hline Var33 & $\begin{array}{l}\text { Physics \& Chemistry NOT compulsory } \\
\text { in Teacher Degrees }\end{array}$ & Var62 & I don't want to go back to math in my life \\
\hline Var34 & Foreign Language ... & & \\
\hline Var35 & Biology \& Geology ... & & \\
\hline Var36 & Mathematics ... & & \\
\hline Var37 & History \& Arts ... & & \\
\hline Var38 & $\begin{array}{l}\text { Language \& Literature NOT } \\
\text { compulsory in Teacher Degrees }\end{array}$ & & \\
\hline
\end{tabular}




\section{Appendix C}

\begin{tabular}{|c|c|}
\hline Taste for disciplines & Multiple responses \\
\hline $\begin{array}{l}\text { Which of the following subjects have you liked most } \\
\text { in pre-university training? } \\
\text { You can choose up to three options. }\end{array}$ & $\begin{array}{l}\text { Mathematics. } \\
\text { Language and Literature. } \\
\text { Physics. } \\
\text { Chemistry. } \\
\text { History. } \\
\text { Biology. } \\
\text { Technology. } \\
\text { Artistic Drawing. } \\
\text { Technical Drawing. } \\
\text { Other (please specify). }\end{array}$ \\
\hline $\begin{array}{l}\text { Why did you decide to study a Teacher Degree? } \\
\text { Please mark up to two options. }\end{array}$ & $\begin{array}{l}\text { I really like to interact with children. } \\
\text { I've been working as a teacher for a long time. } \\
\text { I think it's an exciting career. } \\
\text { I think it's an easier career to study. } \\
\text { I think in this career, I'm more likely to graduate. } \\
\text { Other (please specify your reasons). }\end{array}$ \\
\hline $\begin{array}{l}\text { What subject would you like NOT to be mandatory } \\
\text { in Teachers Degree? } \\
\text { Please choose one or two options. }\end{array}$ & $\begin{array}{c}\text { Language. } \\
\text { History and Geography. } \\
\text { Biology and Geology. } \\
\text { Physics and Chemistry. } \\
\text { Mathematics. } \\
\text { Foreign languages. } \\
\text { Other (indicates which). }\end{array}$ \\
\hline $\begin{array}{l}\text { Please mark the appropriate circle to indicate } \\
\text { your views on the following statements }\end{array}$ & $\begin{array}{l}\text { In Teachers Degrees you should NOT study further Social } \\
\text { Sciences. }\end{array}$ \\
\hline $\begin{array}{l}\text { (Where } 1 \text { is "Totally Disagree"; } 2 \text { is "Disagree"; } \\
\quad 3 \text { is "Agree" and } 4 \text { is "Strongly Agree"). }\end{array}$ & $\begin{array}{l}\text { In Teachers Degrees you should NOT study further } \\
\text { Mathematics. } \\
\text { In Teacher Degrees you should NOT study further } \\
\text { Experimental Sciences. }\end{array}$ \\
\hline & $\begin{array}{l}\text { In Teacher Degrees you should NOT study further Language \& } \\
\text { Literature. } \\
\text { Foreign languages should NOT be further studied in Teacher } \\
\text { Degrees. }\end{array}$ \\
\hline
\end{tabular}




\section{Socio-familiar environment}

Please tell us if any of the following realities occur in your socio-family environment: You can choose more than one option.
Multiple or open responses

At least my father/tutor or my mother/tutor has college degrees.

At least my father/tutor or my mother/tutor has nonuniversity technical studies.

My parents/guardians have no higher education or technical.

Other circumstances.

What I have learned from my family and social environment (society and school) and what I hope in graduate studies is:

The novelty of the contents.

A new point of view on issues of my work.
Sharing my work with others.

The contribution of a theoretical framework to my professional activity.

The possibility of consulting on everyday problems.
Please tell us if any of the following occurs in your family:
I've been taught to love science.

I have been taught to love arts.
Arts abhorred.

None of the above.

Which of the following statements is true?

My mother/father/tutor is or has been a teacher in Child Education or Primary Education.

My mother/father/tutor is or has been a teacher in Secondary Education (CSE, Baccalaureate, VT or School of Languages).

A close person to whom I have frequent treatment is a teacher.

Another related circumstance you want to notice.

Does your parents or tutors have a degree in science or technology (mathematics, physics, chemistry, biology, engineering, etc.), in architecture or in health sciences?

[Open answer]

Please specify your answer.

If the people you have lived with (parents / tutors) DO NOT have training in science or technology, answer the following question: Have you been instilled taste, curiosity, interest, etc., for these disciplines? Briefly describe your experience.

Mathematics and final comments

Regarding Mathematics, what could you say? Please choose up to 3 statements.
Multiple or open responses

I want to keep studying them to better prepare myself as a teacher or teacher.

I don't want to see them again in my life.

I like them a lot, and I think they're important in the training of boys and girls.

If I must study it in the Degree I will do it, very much to my regret.

Other (please specify other answer) 